\title{
Depression and Desynchronization of Temporal Relation in Lars von Trier's Antichrist and Melancholia
}

\begin{abstract}
This article aims to apply Thomas Fuchs' "Psychopathology of Interpersonal Time" to Lars von Trier's films Antichrist and Melancholia. Fuchs examines melancholia in patients with depression resulting from a desynchronization of inner time and common/social time. To successfully restore mental health, an organism thus has to readapt to the socially accepted course of time. My article proposes the debunking of outside/common/social time as a container that accumulates the evilness of humanity, against which the heroines in von Trier's Antichrist and Melancholia resist, and thus the desynchronization or "inhibition of inner time" ensues. Overall, the heroines of both films are conscious of this desynchronization (which is embodied as "rift," a technique in the two films used to deal with the relationship between time and depression) and strive for resynchronization, though not with socially acceptable standards of time which teem with the evil of humanity. In the two films, von Trier rescues depression from a totalizing psychiatric or psychological framework, and he somewhat incorporates it into the force of Nature that overwhelms man's evil. Depression either enhances a force of resistance or brings tranquility as it draws one downward to encounter one's soul, which in Hillman's terms refers to "the images of daimones." Though the two films take different turns, both heroines reimagine liberation in their new/inner time.
\end{abstract}

Keywords: rift, depression, desynchronization, daimones, Lars von Trier.

Justine Shu-Ting KAO

Tamkang University

kiwitreesky@yahoo.com

EKPHRASIS, $1 / 2019$

A MELANCHOLIC EXPLORATION OF HUMANITY

(The Solitude of Man)

pp. 109-122

DOI:10.24193/ekphrasis.21.9

Published First Online: 2019/06/27

\section{Introduction}

Thomas Fuchs, in "Melancholia as a Desynchronization: Towards a Psychopathology of Interpersonal Time," examines melancholia in depressed patients as the result of desynchronization, i.e. an "uncoupling in the temporal relation of organism and environment, or of individual and society" (179). Organisms maintaining a healthy mental life depend on 
"synchronization between endogenous" (chronobiologic/inner) and "exogenous" (social/outside) time-keepers (Fuchs, "Melancholia as a Desynchronization" 180). This chronobiology (inner time), like homoeostasis, changes cyclically over time, continuously synchronizing with outside time (social/common time) so as to maintain its rhythm against the "decaying processes of anorganic nature" (180) in the environment. When chronobiology confronts "temporal discrepancies" (180), an organism starts to operate its "phylogenetically older defense mechanism" (183) to protect itself or restore itself to biological synchronization. If the environmental stress that the organism bears is tremendous, the organism might suffer unpleasant feelingsdrive needs, pain, exhaustion, etc. - which is the process of its inner order fighting against the physical world. This battle is followed by two results: resynchronization and desynchronization. While the former corresponds to a conversion to synchronize with social life, the latter refers to "the uncoupling of the resonance and synchrony of individual and environment" (182) which leads to "a complete desynchronization" (e.g., in the case of depressive melancholia) (182). Depressed patients' awareness of time differs from that of non-depressed people. Although world time goes on, their inner time confronts its inhibition as if time composes a "juxtaposition of two worlds" (184). Their inner time is slower than the outside time, closer to the past, and they are unable to progress toward the future. Fuchs notices the relationship between depression and time disorder (desynchronization between chronobiology and social time), as well as some syndromes or phenomena connected to "a complete desynchronization" ("Melancholia as a Desynchronization" 182). The thesis herein applies the psychoanalysis of time disorder to Lars von Trier's Antichrist and Melancholia in order to develop this notion-staying within an inner time (a new time) without suffering from depression. Maintaining temporal speed synchronicity with outside time is difficult for von Trier's heroines, since they sense the evil inherent in mankind's activities with which they cannot compromise. In this article, I will demonstrate the relationship of desynchronization and depression (those elements that crash the chronobiology) and examine a process of resynchronization as the heroines engage in a constant emotional communication with the Other.

\section{The Earth is Evil}

Von Trier's films dramatize the Earth as evil in the domestic as well as social realms so as to enforce that nowhere can one escape from the chaos reign of nature. Antichrist, von Trier's 2009 Danish psychological horror film, centers on a couple, who after the death of their child seek spiritual recovery in the woods and gradually fall into a violent circle of sexual sadomasochism which ultimately leads to the death of the woman in the midst of the man performing psychotherapy on her. Although depicted as Eden-esque and paradisiacal, the cabin in the woods in which the couple stay is actually more of a hell; there is an unknown power dominating them both, beyond their comprehension. As the male character-a psychologist-practices 
his therapy, persuading the woman into the belief that she will retrieve a kind and tranquil nature through meditation, the woman becomes increasingly grievous and maniacal. The man becomes increasingly sinister, though he is unaware of his evilness or does not acknowledge it. Their relationship metamorphoses from that of therapist-patient to sadomasochistic addicts, as they both indulge in a vicious cycle of self-mutilation, perversion, and aggressivity -including live burial and stabbing with scissors among other acts of violence, culminating in the death of the woman.

Compared to Antichrist, which is based on an allegorical, psychological, and gothic genre, Melancholia, von Trier's science fiction art film released in 2011, depicts the evil of man and collapse of the Earth in a dream-like cosmic destruction. As Honig argues, the filmmaker shows us two calamities. The first concerns the calamity of the planet Melancholia, while the second concerns an evil society based on an obscene economy. In Justine's wedding reception, the heroine's boss, Jack, is a greedy and gluttonous businessman, practicing what Honig defines as "neoliberalism"; he asks the newlywed-employee to meet a work deadline and pushes his nephew Tim to learn the tagline that she has designed. Justine's brother-in-law, John, a typical bourgeois, ignores Justine's emotions and demands that she comply with the wedding reception as part of normal "neoliberal life" (Honig 629). Apart from this, the bourgeois family is engaged in a kind of evil - a selfish father and a cynical mother form a dysfunctional family, for which Justine has no affectional bond as an abandoned child. The heroine is thrown into a neoliberal life for which she is incongruent. She becomes identical to the planet Melancholia, the first calamity in the film. Parallel to the rhythm of the orbiting planet and its impending destruction of the evil Earth, Justine destroys her wedding, alienating herself from the groom. In contrast to Antichrist, for which the denouement does not deliver Earth its release from evilness, Melancholia presents the planet Melancholia as a savior to all as it destroys the evil earth, as embodied in Justine's declaration that "We don't need to grieve for it" (1:31:09).

Von Trier owes much to Marquis de Sade in terms of the perspective that the Earth is evil. ${ }^{1}$ Marquis de Sade reversed the conventional ethical theory that everything is good and originates from God. ${ }^{2}$ Instead, he believed that the universe is dominated by Satan and its axis is evil. In Juliette, de Sade expresses his philosophy about the essence of Nature through the voice of a character:

Je me dis: il existe un Dieu, une main a crée ce que je vois, mais pour le mal ; elle ne se plaît que dans le mal ; le mal est son essence ; tout celui qu'elle nous fait commettre est indispensable à ses plans... (qtd. in Praz 102)

Mario Praz, in The Romantic Agony, remarks upon the Sadean "changeless cruelty of Nature" evident in Romantic writers such as Delacroix, Baudelaire, and Swinburne:

The whole universe is suffering and pain, as in Swinburne's Anactoria: not only do the bodies of men strain in violent action or twist in pain or fall exhausted in agony, not only does the flesh tremble with nerves stretched 
beyond bearing, or languish in mortal pallor: but beasts and plants seem to

vibrate with the same shudder of pain.... (142)

Suffering and pain are woven throughout the entire history of humanity; evil is a constantly vivid performer throughout time. Though goodness still exists on the evil Earth and exists in rarified cases, de Sade's good characters are proffered as victim or "degraded to the status of instruments for provoking the so-called divine ecstasy of destruction" (Praz 104). This is exemplified by the case of Sade's Justine, in which the heroine is engaged in a series of misfortunes and ends miserable due to her virtue or goodness. Von Trier's Justine resembles de Sade's, as both of them are portrayed as victims in inherently evil world. Both are morose and depressed, incompatible with their surroundings. Both are rescued by natural calamity. Whereas de Sade's Justine is struck by a lightning bolt, von Trier's is integrated with the planet Melancholia which destroys not only her, but indeed all creatures on Earth. ${ }^{3}$

\section{Synchronization with Outside Time}

Von Trier's characters are irrevocably involved in the evil world; their energy of activities lies in the synchronization of the individual and the environment, i.e. maintaining temporal speed with regard to outside time. Von Trier presents men as participants and perpetrators of evil; men are hardwired to do evil. As Dienstag in "Evils of Representation in Europa and Melancholia" notes, men in von Trier's films "perpetrate evil and are so blind to it. They constantly proclaim their innocence and objectivity and hide their selfishness" (298). The man in Antichrist is an exonerator who masks himself as a psychotherapist. While the woman is grief-stricken and guilty for the death of the child, the man is not as sorrowful as she is, and as such he becomes the one who "helps" the woman to work through her sadness. The man tells the woman that he, as her husband, is entrusted to be her doctor; he then adopts the role of guiding the woman to recover her sanity and a semblance of order within her life. The woman is honest in facing her sense of guilt, while the man exonerates his guilt, transforming from a grief-stricken parent to a therapist correcting the behavior of an "immoral woman." The man accuses the woman of insatiable lust; he seeks to control or desexualize the woman-patient through a medical system while rationalizing his over-sexuality and exonerating his guilt for the death of their child. The scene regarding the violent intercourse of the couple at the base of an ominous dead tree ${ }^{4}$ suggests that the man has succumbed to evil.

In addition, von Trier's Antichrist concerns the suppression and carnage of women, debunking man's history an evil one. The man's actions bear comparison to, as Beattie points out, "a genocidal culture" in the "medieval images of burning and tortured women" ("Antichrist: The Visual Theology of Lars Von Trier"). During the process of the mental treatment, the man unconsciously replicates the consciousness of the witch-hunting executioners who authorized their executions in order to repress and suppress women. In the accusation claimed against the witches, the witch-hunters 
denied that they had received pleasure as sadistic voyeurs from the sexual abuse imposed on the women in question. Malleus Maleficarum states, "All witchcraft comes from carnal lust, which is in women insatiable" (qtd. in "Persecuting Witches and Witchcraft"). In much the same vein, the man in von Trier's Antichrist hides his sadistic/voyeuristic impulses. Through the lens of the suffering of the woman, Antichrist implies a collective violence that men have been imposing on women. The man here represents those who rationalize themselves as "the God-man" whose "misogynistic cult has sacrificed generations of women through persecution, burning and torture, while implanting in women themselves a deeply rooted sense of guilt and self-loathing" (Beattie, "Antichrist: The Visual Theology of Lars Von Trier").

Evil in Melancholia is associated with the socio-economic system that practices the teleological form of neoliberalism. ${ }^{6}$ The concepts of money and working are repeatedly emphasized as the wedding proceeds. The wedding is a microcosm of the evil universe, and the time in space is filled with evil activities. The teleology of the wedding reception for John, Justine's brother-in-law, is a demonstration of wealth based on the concept that people believe wealth brings happiness. The wedding begins with a long luxury limousine. The groom has purchased for the bride a plot of land with apple trees which resembles Eden (Von Trier's presentation of Eden is not a place of serenity and happiness). John underscores the fact that the wedding has cost him a great amount of money. None of the guests burst into anger or leave when they are kept waiting for a long period of time in the atmosphere of the luxury wedding reception. People believe or are asked to believe that the luxury limo, expensive cakes, hot air balloon, apple-tree land, and golf all enhance the value of the wedding in terms of neoliberalism, enabling their transcendence into a world of happiness. Martel, in "Against Thinning and Teleology," notes danger in teleology: "Teleology then is the mechanism that allows us a 'radical hope.' It guarantees that whatever happens next-even if it happens to be unrecognizable to us as we are currently formed-will be something that we can ultimately recognize as commensurate with our current values" (643). Teleology is a political discourse used to persuade people to conform, cooperate, and "normalize" when given a blueprint of hope which in reality is illusion. Justine is unwillingly demanded to access the teleological form of neoliberal economy; and she is asked to hide her depression-or rather to mediate/ ignore her depression in the pursuit of happiness. Her wedding is ruined by the obscene products of economy, manifested in her boss (Jack) sending his nephew (Tim) to pursue her throughout the wedding reception, with the aim of obtaining at all costs the business intelligence expressed by the tagline she has been entrusted with creating. Evil permeates the socio-economic system, dooming the wedding; the wedding is "a sign of the incapacity of old rituals to meet the demands of the moment" in "the new political economic context" (Honig 629).

Whether the evilness of humanity continues on in common/social time depends on an organism's desire to maintain satiety in evil activities. As an organism undergoes 
"synchronization between endogenous" (chronobiologic/inner) and "exogenous" (social/outside) time-keepers (Fuchs, "Melancholia as a Desynchronization" 180), ${ }^{7}$ it confronts the decision between being good or evil. Being evil is man's inclination, as de Sade notes. In accordance with that viewpoint, being evil is also the essence of life for most of von Trier's characters. To restore synchronization with outside time, an organism needs to conquer these "temporal discrepancies" (Fuchs, "Melancholia as a Desynchronization" 180)-periodical discrepancies-and the price might be unpleasant feelings or drive needs as seen in the characters of Antichrist and Melancholia. When returning to resynchronization, most organisms regenerate the evilness of humanity in the outside world.

The evilness of humanity rampages the earth - in time and space-a fact to which both the heroines of Antichrist and Melancholia are sentient, and within them arises a new time experience in opposition to outside time. As the woman in Antichrist declares to the man that Nature is the Church of Satan, she is aware of a power unknown to the man that can destroy the evilness of humanity. Perhaps she has the power of a witch or seer who can perceive premonitions, including mankind's evil activities, and this power is enhanced when she falls into a depression that brings forth a type of hypersensitivity. In Melancholia, when the planet Melancholia is first perceived, and everyone is in ecstasy and excited in appreciation of its beauty, Justine becomes morose and depressed. She is completely catatonic, so numb that she is unable to take meals or bathe herself. That her favorite meatball tastes of ash suggests the delicious food is nothing but flesh cooked from the body blocks of animals killed by human beings. She perceives that cruelty inundates the common social course of time/life: the mechanism of one's life depends on the death of others. Von Trier endows his female characters with the capability of perceiving evil while most of his male characters "lack vision" or "see only in a conventional way" (Dienstag 298). His heroines understand well the essence of the Earth; put up with the burden of horror that men cause, then disintegrate or resist convention and conform to the power of Nature that effectively ends the evil Earth.

\section{Rift, Desynchronization, and Languorous Tempo}

Much as the woman in Antichrist is violently cast out of the symbolic order due to her refusal to cooperate with the psychotherapist, so Justine in Melancholia refuses to enter the symbolic order/social order. They remain in "abjection" 8 or possess the ability to traverse to an unnamable space, exclusive from the symbolic order. Like the male characters, they experience "temporal discrepancies" (Fuchs, "Melancholia as a Desynchronization" 180), yet they do not undergo resynchronization with the outside time teeming with evil activities, but instead fall apart from it (desynchronization); they stay within their inner time.

Hillman's polycentric realm in Blue Fire can be read as the part that appraises the desynchronization from social time as the most valuable part of the soul. Hillman 
believes that the search for soul is structured as a dimension traveling downward, without the control by the ego: "the psyche presents its own imaginal dimensions, operates freely without words, and is constituted of multiple personalities" (48). "We can describe the psyche as a polycentric realm of nonverbal, nonspatial images" (Hillman 48-49). Hillman describes the images in dreams as "demonic" (63) shadows of life and death that guard the soul. The psyche in its spiritual time journal reaches the realm of the underworld parallel to Kristeva's abjection not belonging to the symbolic order. Images of daimones interrupt the social life that the soul goes along with, and their end is to calm, guard, and nourish the psyche while the psyche is searching for self-understanding.

Von Trier rescues depression from totalizing psychiatric or psychological frameworks that force the individual to synchronize with social time. Depression should not be seen as a disease, and instead it can be seen as a power of empathy that brings us refuge, creativity, tranquility, and happiness, as we see in the character of Justine at the end of the film. Hillman produces new language and ways of thinking about depression which enhance the value of depression.

Depression is essential to the tragic sense of life. It moistens the dry soul, and dries the wet. It brings refuge, limitation, focus, gravity, weight, and humble powerlessness. It reminds of death. The true revolution begins in the individual who can be true to his or her depression. Neither jerking oneself out of it, caught in cycles of hope and despair, nor suffering it through till it turns, nor theologizing it-but discovering the consciousness and depths it wants. So begins the revolution [on] behalf of soul. (Re-Visioning Psychology qtd. in Hillman 153)

Depression helps the woman in Antichrist break the psychotherapist framework that the man imposes on the woman. In much the same vein, depression in Melancholia breaks the framework of neoliberalism and teleology. Justine "remains faithful to the 'remainder' that cannot be integrated" (Friedlander 206).

The power of resistance as well as the search for demonic shadows in the unconscious is embodied in the rift (or the crack), which is symbolic of inhibition or, as Fuchs puts it, "the explicit experience of temporality."

The explicit experience of temporality superimposes itself on the implicit mode when the steady duration of primary "becoming" (Bergson) or oblivious activity is interrupted by the sudden: such as the shock of a sudden loud noise, surprised amazement, a stab of disappointment or shame, a break in an interpersonal relation or a painful loss. In such moments, pure lived temporality sustains a rift: "now" and "no longer" are disconnected and create an elemental segmentation of time. ("Temporality and Psychopathology" 79)

In Antichrist, von Trier expresses "the rift" in nonhuman objects - trees, animals, insects, a bridge, an icon of the "woman Devil," etc. In Melancholia, "the rift" is set in 
trees, horses, the 19th hole, Black River, planets, etc. The rift reflects, as "T. S. Eliot [once] diagnosed the modern condition," a gap between "thought and emotion, intellect and sensation, and a general failure to achieve 'unity of sensibility'" (Ratner 188). Despite the loss of subjective sense of temporal continuity, the rift is also a sign of potential rupture that contains the force against the symbolic order as well as a refusal to synchronize with outside time. The rift, when sealed, is suppressed in the unnamable realm of the abject, which is ignored and abominated, and excluded from the parental symbolic language. Once the suture breaks (e.g., the return of trauma), a force of resistance erupts from the rift, revolting against the Name of Father. It corresponds to the wrath of the woman, who is being shaped and integrated into Nature through inner time. The rift does not exist simply as "a nihilist delusion" within the inner time of the depressed. It is embodied in the real world apparent to von Trier's heroines. For example, the leech in Antichrist is a sign of the fury of Nature while it is drooping over the roof and oozing out of a suture. A self-disemboweling fox is another example relevant to the force of resistance in Nature; it claims to the man that the dominator on Earth is not man, but Nature/Satan/Chaos. An icon of Satan appears in the wood cabin where the man assumes the role of Adam guarding Eden. Compared to the expression of the rift through a gothic and sexual (horror) lens, the rift in Melancholia is presented in a more delicate movement, echoing the languorous tempo of the inner world of the depressed. As the rift appears, the repressed returns; the rift is shown in a supernatural space where one experiences asynchronies, a disorder of the outside, but orients itself towards one's inner time. Desynchronized with outside social/common time, they orient themselves toward a new chronobiology, coupling with their inner tempo of time corresponding with Nature in the environment unbeknownst to von Trier's male characters.

Both heroines in the films are conscious of the rift and escape to their inner time as they travel downward to a dimension beyond the nominal social order/time. Their inner time is embodied by a languorous tempo. The languorous tempo in the opening scene of Antichrist is achieved through the contrast between life/sex and death, infancy and adulthood, and pleasure and suffering. It suggests the heroine is going to experience "temporal discrepancies" (Fuchs, "Melancholia as a Desynchronization" 180) that lead to depression, moving to a new time. In Melancholia, accompanied by the prelude to Richard Wagner's opera Tristan und Isolde, there is an image of dead birds falling down behind the face of a depressed woman, which is followed by a still golf course, a still hunting scene decorated with falling dead birds, and a planet growing larger and more visible. Then, there are a series of objects moving in a languorous tempo: a woman holding a child, a horse falling backward, a bride standing distant from a child and a woman, a planet slowly turning around, Justine becoming telepathic, a bride drawling behind her dead tree-stems, a child paring the stem, a bride drifting on water, and the overlapping image of the planet and Justine. Richard Wagner's Tristan und Isolde symbolizes, as Zimmer in The King and 
the Corpse notes, "a nostalgic worship of dissolution, a loving sense for the mysterious descent into the womb of the generating powers" (199). The orchestrated images in melody celebrate the dissolution of time and space on Earth. The tempo of each object associated with the rift is languorous as if it is going to swallow up the rapid change (and trauma) in human history; and indeed all is eventually consumed by the planet.

\section{From Depression to Resynchronization}

The heroines in von Trier's films, who have been desynchronized with outside time, compose or imagine their inner time filled with a material universe framed out of something to which they are telepathic in Nature. Their emotions and depressions are reactions against coupling with social time.

The tussle between the man and woman in Antichrist is unabated, even aggravating. The woman is not simply a human, but a supernatural power that witches possess and have awakened in her, and she is merging into Nature. She crosses a bridge, which is part of the rift symbolic of the gap between the masculine/feminine, thought/ emotions, and the spiritual/material, reaching a grassy field symbolic of the time of the lost/prelapsarian Eden. She is congruent to Nature-a violent and gloomy nature, resisting the man's manipulation. On the one hand, the power of anti-coercion is growing in her. Before formation of anti-coercion, she experiences "periodical discrepancies" (Fuchs, "Melancholia as a Desynchronization" 180) and falls prey to disturbances - the sense of grief and guilt, drive needs in sexuality, exhaustion, etc., that lead her into masochism, having submitted herself to the man's sadism. As she slips into a new time in an "unnamable" (Kristeva 61) realm, she demands the man comply with her. She pursues and attacks the man when the latter escapes and intends to rid himself of her. She smashes and masturbates him when he is unconscious. She fears that the man will escape again; she drills a hole through his leg and fixes the leg to the ground with a heavy grindstone. The man awakens, runs, and hides in a foxhole. Incensed, she buries him with a shovel. The woman does not intend to kill the man; her violence is directed towards the destruction of the man's subjectivity (ego). She slips into the unnamable realm of the "abject" (Kristeva 4) and desires to retrieve an archaic, primary affection with the man. Later, she is remorseful when he is going to be buried alive. She helps the man back to the cabin - the cabin of witch hunting and execution.

On the other hand, the woman enacts the plot of witch-hunting in her inner time and allows the murder to happen in real world; she does so in order to kill herself through the hand of the man (suicide). The woman feels guilty when, in a flashback, she watches her child climbing up to the window. (Previously, she has deformed the feet of the child.) She has a prophetic sight about the replication of the witch execution in the cabin; she tells the man that when the three beggars arrive, someone must die. The three wounded animals - the fox, the deer and the crow-which represent "pain, grief, and despair" are the three beggars she refers to, and they have 
appeared respectively in the film. The woman is aware that she is going to be killed as the hailstorm begins in the wood. Previously, she has researched the history of the witchcrafts and witch hunting. The accused witch-women had the power to summon hailstorms. Through research on the history of the persecution of women, this woman is sympathetic to the women and has a new contact for a feminine relationship. She is prepared to become a victim or an "Antichrist" - the one who was accused of child abuse and over-sexuality. As she cuts off her clitoris with scissors, she does not intend to evoke sadomasochist pleasure, but administer a self-disemboweling pain so as to identify herself with the victims in the history of witch hunting. It is somewhat similar to the alchemist's spiritual trial for the deepest intimacies of existence, not through integration into any forms of unity, but through desire for self-immolation. The man is driven by impulse and desire for pain voyeurism. When attracted by her self-mutilation, he desires to have sex with the woman. While being stabbed on the back with the scissors by the woman, he strangles her to death, making a sinister face in the midst of killing her. The man then burns her on a pyre, just as the persecuted witches were burned on a pile of wood. After the horrible event, he walks alone, crippled, out of the cabin. Antichrist serves much as an allusion to the witchcraft trials (the control of sexuality in history), and much about the man and the woman miserably involved in an evil essence that they cannot escape. Nevertheless, von Trier shows the man as a despised, abandoned creature, who has been participating in the lie of an anthropocentric world. In contrast, the director elevates the woman to divinity and exposes her supernatural force. The woman reimagines the material universe frame ("the Church of Satan") in her inner time and resynchronizes the inner time with Nature, to which she is telepathic and on which she depends for liberating herself through pain and suicide.

While the woman identifies herself with the persecuted witches in resistance and a re-imagination of the movement of Nature towards her destruction, Justine in Melancholia is completely incongruent to the activities of the common/social time. As MacCabe says, "Justine's depression enjoys the ultimate pathetic fallacy-her inner blackness is mirrored by an approaching rogue planet, named Melancholia, a typical light touch from von Trier" (63). Von Trier opposes the heroine's intuition to John's cult of (pseudo)science and social frame. In part one, the heroine's depression is repressed and bursts out within the cultural frame that requires her to dispel negative emotions. Her depression is shown in a montage revolving around the scene of the wedding reception (cultural frame) and "the recessive space" (unconscious) that happens in the time of "eclipse." The limousine struggling along a dirt road, Justine's wandering away from the reception several times, and the discovery of the planet Melancholiaall are symbolic of the time of eclipse identical to the approaching of the planet that will dispel the insignificance of the cultural models. Similar to the heroine in Antichrist, Justine entangles herself in the past when she desynchronizes from outside time. She (deliberately) lags behind the "transient herself world-time." In one withdrawal from 
the wedding reception (due to the stress imposed by her boss, who is been asking her to hand over the tagline she has created), Justine stays in a room alone observing The Land of Cockaigne, a 1567 oil painting by Pieter Bruegel the Elder, which illustrates a comical middle-age society where all restrictions are defied. Just as the research book about witch hunting in Antichrist signifies the woman's imaginary space, so the themes in the oil painting about sexual liberty and resistance to authority mirror the psychological introspection of the heroine in Melancholia. She gradually slips into asynchrony of time, resisting against the social/symbolic framework. Resentful of these cultural models, the heroine in the wedding wanders away, heading to the far end of the golf course, watching the night sky. In another escape, she withdraws and bathes. She refuses the groom while he is promising her a peaceful land with apple trees, and then escapes to a sand trap, having sex with a stranger (a colleague, who is sent by her boss to demand the tagline). Eventually, she is completely depressed, suffering paralysis and somatic illness. Nevertheless, the heroine (in part two of the film) resynchronizes time, not with the evil social world from which she has escaped, but with a new time corresponding to the daimones of soul. She wanders off at night into a forest where she bathes naked on a riverbank, smiles to the moon (or the planet Melancholia), sharing "incestuous longings" with her sister, Claire (Figlerowicz 24). At that moment, she retrieves love that she cannot find from her selfish father and cynical mother; an abandoned child now encounters the Other. The scene in the moonlight renders a gothic and destructive post-human condition. ${ }^{9}$ As the heroine's resonances with the moon or the planet facilitate the development of a "nihilistic delusion" (Fuchs, "Melancholia as a Desynchronization" 184) about the annihilation of all (including all evil activities on Earth) in her inner time, this delusion in her inner time parallels cosmic/real time. In other words, her inner time synchronizes with the tempo of the planet Melancholia which is approaching the Earth and will disintegrate all individual subjects. That synchronization with the planet is a contact with things more profound. In accordance with the tempo of the destructive planet, she deviates from a neoliberal world based on discourse of teleology or illusionary benign notions, and as such she is no longer depression-ridden.

\section{Conclusion-Ecstatic Destruction}

Both heroines of the films Antichrist and Melancholia are conscious of the rift in history and strive for liberation in their resynchronization with the Other in a new time. The woman in Antichrist is typical of von Trier's heroines, who are framed in a community and eventually emotionally break down when the consciousness of divinity becomes awake. Her emotions and physical struggle with the man are reactions against collective violence-repression and suppression-against women. Through the diachronic form of time-space, the filmmaker intertwines the theme of collective violence with the history of the witchcraft trials. The complex diachronic form of time-space is eventually incorporated into the mental world of the heroine as 
a new form of time-space. The heroine's re-imagination of the persecution frame and the man's cultural frame (e.g., psychotherapy) keep overlapping in a conflict until the effect of sadness is produced. There is no comic relief in the end. The last scene shows a vicious circle in human history: hundreds of women climbing up the mountain and wandering towards life and liberty while a man, who stands confounded and looks fixedly at them, perhaps, with the male gaze, is symbolic of the form of suppression. Nevertheless, the heroine has created a new time where she has merged into the power of resistance from the witches whose spirits never die. In contrast, the anxiety and fear in Melancholia disperse when the planet makes its terminal rotation and hits the Earth. The last scene dispels collective melancholy and implies that all tragedies that involve human activities are something trivial compared to cosmic destruction. The heroine, guiding her sister and nephew, stays calm in a "magic cave" which they have constructed-not for surviving the catastrophe, but for enduring "the most unthinkable of all abandonments" (Honig 630). Von Trier inherits from de Sade his interpretation of the Earth as an evil one, yet he does not completely conform to the philosophy. He revises de Sade's "the divine ecstasy of destruction" (Praz 104): Humanity's destruction of others-mostly women-victims and animals - is not the end of the Universe; conversely, a greater power unknown to men which brings destruction to all, as the planet Melancholia does, is the aim of Universe. Von Trier's cosmic destruction is an ecstatic end of suffering on Earth or at a bare minimum, as Figlerowicz notes, comic relief.

\section{Endnotes}

1 See Merola's “Mediating Anthropocene Planetary Attachments," page 263.

2 Psalm 24:1: "The earth is the LORD'S, and all it contains, The world, and those who dwell in it." 1 Corinthians 10:26: “FOR THE EARTH IS THE LORD'S, AND ALL IT CONTAINS." Psalm 50:12: "If I were hungry I would not tell you, For the world is Mine, and all it contains." Psalm 104:24: "O LORD, how many are Your works! In wisdom You have made them all; The earth is full of Your possessions."

3 Bess in Breaking the Waves (Lars von Trier 1996) and Selma in Dancer in the Dark (Lars von Trier 2000) are other of von Trier's examples that correspond to de Sade's assumption that goodness is degraded as victim.

4 In "Blakean Trees in Lars Von Trier's Antichrist (2009)," Roger Whitson likens the tree imagery to Blakean Tree of Mystery: "Tree imagery appears in many places in Blake's Work. 'The Human Abstract' imagines the mythical tree of mystery which ' $\mathrm{t}]$ he Gods of earth and sea/Sought thro' Nature to find this Tree' but Blake says that this search 'was all in vain;/There grows one in the Human Brain' (11. 21-4; E27). The Marriage of Heaven and Hell reminds us that 'A fool sees not the same tree that a wise man sees' (7; E35). The Tree of Mystery appears as a central figure in Vala, or the Four Zoas, where it becomes different things to different characters."

5 The witch trial executioners who imposed sexual abuse on the persecuted witches, including applying the red-hot tongs to the breasts and stretching the bodies on racks and wheels, before those witches were killed by being burned (alive) at a stake or drowned. “The women's sex 
organs provided special attraction for the male torturer," notes Nancy van Vuuren (qtd. in "Holy Horrors: Witch-Hunts").

6 Neoliberalism, based on nineteenth century laissez-faire economic liberalism, aims to achieve economic privatization, free trade, and reductions in government spending. The twentiethcentury resurgence of laissez-faire economic liberalism emerged in the early 1930s with a desire to overwhelm classical liberalism, or perhaps seeking a middle ground between classical liberalism and socialist planning. Neoliberalism has sparked the economic market for decades, yet the impact of the global 2008-2009 crisis provoked vehement critics of neoliberal policies. As Harvey notes, "the era of neoliberalization also happens to be the era of the fastest mass extinction of species in the Earth's recent history" (173).

7 Fuchs in "Temporality and Psychopathology" associates implicit temporality and the basic energetic momentum of mental life. Subjective consciousness of continuity or temporal unity is the key for maintaining stability of mental life: "The second prerequisite for implicit temporality is the basic 'energetic' momentum of mental life which can be expressed by concepts such as drive, striving, urge or affection....as the self-affection or sense of aliveness which may be regarded as the essence of subjective life" (Fuchs 78).

8 In Powers of Horror, Kristeva offers the description of inner space, which I think can illustrate an organism's "slow-up time" phenomena. The critic notes that there is an ingrained clear boundary between nature and society in a symbolic order that defends against "abjection" - an ambiguous realm that the "I" fears and eschews. "These body [of abjection] fluids, this defilement, this shit are what life withstands, hardly and with difficulty, on the part of death. There, I am at the border of my condition as a living being" (Kristeva 3). Kristeva is concerned that the Self may slip into "the unnamable realm of the abject" if the Self is driven by an instinct towards its archaic, pure, primary self. That instinct, repressed well in the world of taboos, now, in an outburst of neurotic illnesses - narcissistic hallucination, hysteria, paranoia, madness, etc. - drives the Self to the verge of the abyss; it is the path to the object of the desire, the body of the mother.

9 For more discussion about the post-human in Lars von Trier, see Merola, Nicole, "Mediating Anthropocene Planetary Attachments: Lars von Trier's Melancholia."

\section{Works Cited}

Antichrist. Directed by Lars von Trier, Nordisk Film Distribution, 2009.

Melancholia. Directed by Lars von Trier, Nordisk Film/Les films du losange/ Concorde Filmverleih/BIM Distribuzione, 2011.

Beattie, Tina. "Antichrist: The Visual Theology of Lars Von Trier." openDemocracy, 13 Aug. 2009, www.opendemocracy.net/en/antichrist-the-visual-theology-of-lars-von-trier/.

Cline, Austin. "Persecuting Witches and Witchcraft." ThoughtCo., 25 Oct. 2017, www. thoughtco.com/persecuting-witches-and-witchcraft-4123033.

Dienstag, Joshua Foa. "Evils of Representation in Europa and Melancholia." Politics, Theory, and Film: Critical Encounters with Lars von Trier, edited by Bonnie Honig and Lori J. Marso, Oxford UP, 2016, pp. 285-304.

Fuchs, Thomas. "Melancholia as a Desynchronization: Towards a Psychopathology of Interpersonal Time." Psychopathology, vol. 34, 2001, pp. 179-186.

---. "Temporality and Psychopathology." Phenomenology and the Cognitive Sciences, vol. 12, no. 1, 2013, pp.75-104. 
Figlerowicz, Marta. "Comedy of Abandon: Lars von Trier's Melancholia." Film Quarterly, vol. 65 , no. 4, 2012, pp. 21-26.

Friedlander, Jennifer. "How to Face Nothing: Melancholia and the Feminine." Lars von Trier's Women, edited by Rex Butler and David Denny, Bloomsbury Publishing, 2016, pp. 201-214.

Harvey, David. A Brief History of Neoliberalism. Oxford UP, 2005.

Haught, James A. "Holy Horrors: Witch-Hunts." Church and State Press, 5 Feb. 2017, http://churchandstate.org.uk/2016/11/holy-horrors-witch-hunts/.

Hillman, James. A Blue Fire: Selected Writings. Edited by Thomas Moore, Harper Perennial, 1991.

Honig, Bonnie. “Public Things: Jonathan Lear's 'Radical Hope,' Lars von Trier's`Melancholia,' and the Democratic Need." Political Research Quarterly, vol. 68, no. 3, 2015, pp. 623-636.

Kristeva, Julia. Powers of Horror: An Essay on Abjection. Translated by Leon S. Roudiez, Columbia UP, 1982.

MacCabe, Colin. "Riviera Eschatology." Film Quarterly, vol. 65, no. 1, 2011, pp. 63-65.

Martel, James. "Against Thinning and Teleology: Politics and Objects in the Face of Catastrophe in Lear and Von Trier." Political Research Quarterly, vol. 68, no. 3, 2015, pp. 642-646.

Merola, Nicole, "Mediating Anthropocene Planetary Attachments: Lars von Trier's Melancholia." Design, Mediation, and the Posthuman, edited by Dennis M. Weiss, Amy D. Propen, and Colbey Emmerson Reid, Lexington Books, 2014, pp. 249-268.

Praz, Mario. The Romantic Agony. Translated by Angus Davidson, Meridian Books, 1956.

Ratner, Carl. "Macro Culture and Psychology." Macro Cultural Psychology: A Political Philosophy of Mind. Oxford UP, 2012, pp.139-222.

Haught, James A. "Holy Horrors: Witch-Hunts." Church and State Press, 5 Feb. 2017, http://churchandstate.org.uk/2016/11/holy-horrors-witch-hunts/.

Whitson, Roger. "Blakean Trees in Lars Von Trier's Antichrist (2009)." Zoamorphosis I The Blake 2.0 Blog: William Blake in art, music, film, and literature, 12 Jan. 2011, http:// zoamorphosis.com/2011/01/blakean-trees-in-lars-von-triers-antichrist-2009/.

Zimmer, Heinrich. The King and the Corpse: Tales of the Soul's Conquest of Evil. Edited by Joseph Campbell, Princeton UP, 1993. 